\title{
Aplikasi Mobile Zagiyan ( Zaringan Digital Nelayan) Dalam Menunjang Produktivitas Dan Keselamatan, Dan Kesehatan Nelayan ( Studi Kasus Kelompok Nelayan Percut)
}

\author{
T. Henny Febriana Harumy ${ }^{1}$, Hanifah M.Z.N. Amrul ${ }^{2}$ \\ ${ }^{1,2}$ Jurusan Sistem Komputer, Fakultas Sains \&Teknologi, Universitas Pembangunan \\ Pancabudi \\ e-mail: ${ }^{1}$ hennyharumy@ hotmail.com, ${ }^{2}$ hanifahmutia@dosen.pancabudi.ac.id
}

\begin{abstract}
The goal to be achieved from this application is to optimize Mobile Application Zagiyan (Digital Fisherman's Zip) In Supporting Productivity And Safety, And Fisherman Health (Case Study of Fisherman Fisher Group). The main target of this Service is to implement Zagiyan mobile software and application system with various features such as Fish Price Features, Pendapatam Report, cooperative info, Puskesmas info, check in, report, panic and others. The result of this activity is Fishermen familiar with Zagiyan android app for Increasing productivity, safety and health of coastal community. The Accuracy Level of this application reaches 90\%. This application has also been implemented in some daerha of Deli and Percut Chart.This application is expected to be a solution for all Indonesian fishermen.
\end{abstract}

\begin{abstract}
Abstrak
Tujuan yang ingin dicapai dari aplikasi ini adalah mengoptimalkan Aplikasi Mobile Zagiyan (Zaringan Digital Nelayan) Dalam Menunjang Produktivitas Dan Keselamatan, Dan Kesehatan Nelayan (Studi Kasus Kelompok Nelayan Percut). Target utama adalah mengimplementasikan software dan system aplikasi mobile Zagiyan dengan berbagai fitur seperti fitur harga ikan, laporan pendapatam, info koperasi , info puskesmas, check in, report, panic dan lain lain. Hasil dari kegiatan ini adalah Nelayan mengenal aplikasi android Zagiyan untuk peningkatan produktivitas, keselamatan dan kesehatan masyarakat pesisir. Tingkat Keakuratan aplikasi ini mencapai 90\% . Aplikasi ini juga telah diterapkan di beberapa daerah yaitu Bagan Deli dan Percut .Aplikasi ini diharapkan menjadi solusi bagi seluruh nelayan Indonesia.
\end{abstract}

Kata Kunci : Aplikasi Mobile, Android, Zagiyan

\section{PENDAHULUAN}

Desa Bagan Percut merupakan salah satu wilayah yang berada di Pesisir Timur Sumatera Utara. Desa ini berbatasan langsung dengan Selat Malaka di sebelah Timurnya. Sebagian besar masyarakat di Desa ini berprofesi sebagai nelayan. Kalau dilihat dari kehidupan sehari-hari nelayan yang berada di desa ini sebagian besar masih memiliki penghasilan yang pas-pasan. Kehidupan para nelayan di desa bagan percut sangat sederhana, nelayan kelaut hanya mengandalkan perahu dengan mesin tempel dan tanpa dibekali dengan ilmu pengetahuan. Ilmu yang dimiliki nelayan hanya diperoleh secara turun temurun dari nenek moyangnya. Hasil tangkapan nelayan sangat tidak menentu, saat beruntung mereka bisa membawa ikan dengan jumlah puluhan kilogram dan disaat merugi terkadang hanya mendapatkan hasil beberapa kilo saja. Kelompok nelayan yang menjadi mitra dalam Pengabdian ini belum memiliki manajemen usaha yang baik. 
Sebagian besar anggota dari kelompok nelayan ini hanya memiliki tujuan mencari ikan dan kemudian dijual, dapat uang untuk makan dan uang sekolah bagi anak-anaknya mereka merasa itu sudah cukup. Dalam melakukan aktivitas sehari-hari nelayan tersebut tidak memiliki ilmu tentang bagaimana menentukan lokasi yang tepat untuk mencari ikan, tidak mengetahui kondisi cuaca dan terkadang dalam memasarkan produknya di curangi oleh para tengkulak. Kondisi yang tidak jauh berbeda juga dialami oleh petambak Bandeng di daerah Banjarpanji, seperti yang diungkapkan oleh Rahmawati et. al., (2014) bahwa petani bandeng harus menjual hasil panen ke agen, dan disaat penjualan yang diterima hanya nota saja yang berisi total (kiloan) Bandeng dan harga perkilo tanpa kepastian kapan mereka akan menerima pembayaran [5]. Didaerah Bagan Percut nelayan harus menjual ikan hasil tangkapannya ke tengkulak karena telah memiliki hutang sebelumnya. Seperti kita ketahui saat ini sistem penangkapan ikan sudah mulai berkembang di beberapa wilayah termasuk metode menentukan area tangkapan ikan. Hasil penelitian dilakukan oleh Harahap dan Yanuarsyah (2012) bahwa dengan menggunakan aplikasi sistem informasi geografis nelayan dapat menentukan peta alternatif jalur-jalur penangkapan ikan. Berdasarkan hal tersebut maka sistem yang akan dikenalkan pada masyarakat (nelayan) dapat membantu dalam proses penangkapan ikan [1].

Berdasarkan uraian pada latar belakang masalah di atas, maka dapat dirumuskan permasalahan sebagai berikut:

1. Bagaimana merancang Aplikasi Mobile Zagiyan ?

2. Bagaimana menganalisis Aplikasi Mobile Zagiyan ?

3. Bagaimana implementasi dan pengujian Aplikasi Mobile Zagiyan?

\section{METODOLOGI PENELITIAN}

\subsection{Pengumpulan Data}

Pengumpulan Data Dari Penelitian Ini adalah sebagai berikut :

1. Wawancara

2. Observasi Lapangan

3. Literatur

\section{2 Konsep Teori}

Pengertian sistem menurut para ahli, konsep dasar sistem :

Menurut Fat pengertian sistem adalah sebagai berikut : Sistem adalah suatu himpunan "benda" nyata atau abstrak ( $a$ set of thing) yang terdiri dari bagian-bagian atau komponen-komponen yang saling berkaitan, berhubungan, ketergantungan, saling mendukung, yang secara keseluruhan bersatu dalam satu kesatuan (unity) untuk mencapai tujuan tertentu secara efisien dan efektif. Dengan demikian sistem adalah suatu jaringan kerja dari prosedur-prosedur yang saling berhubungan, berkumpul bersama-sama untuk melakukan kegiatan atau untuk melakukan sasaran yang tertentu. Pendekatan sistem yang merupakan jaringan kerja dari prosedur lebih menekankan urutan-urutan di dalam sistem. Menurut Richard F. Neuschel suatu prosedur adalah suatu urutan operasi kelrikal (tulismenulis), yang melibatkan beberapa orang didalam satu atau lebih departemen, yang diterapkan untuk menjamin penanganan yang seragam dari transaksi-transaksi bisnis yang terjadi [2]. 


\subsection{Pengertian Nelayan}

Nelayan adalah orang yang hidup dari mata pencaharian hasil laut. Di Indonesia para nelayan biasanya bermukim di daerah pinggir pantai atau pesisir laut. Komunitas nelayan adalah kelompok orang yang bermata pencaharian hasil laut dan tinggal di desadesa atau pesisir [6]. Ciri komunitas nelayan dapat dilihat dari berbagai segi, sebagai berikut:

a. Segi mata pencaharian, nelayan adalah mereka yang segala aktivitasnya berkaitan dengan lingkungan laut dan pesisir, atau mereka yang menjadikan perikanan sebagai mata pencaharian mereka.

b. Segi cara hidup, komunitas nelayan adalah komunitas gotong royong. Kebutuhan gotong royong dan tolong menolong terasa sangat penting pada saat untuk mengatasi keadaan yang menuntut pengeluaran biaya besar dan pengerahan tenaga yang banyak, seperti saat berlayar, membangun rumah atau tanggul penahan gelombang di sekitar desa.

c. Segi ketrampilan, meskipun pekerjaan nelayan adalah pekerjaan berat namun pada umumnya mereka hanya memiliki ketrampilan sederhana. Kebanyakan mereka bekerja sebagai nelayan adalah profesi yang diturunkan oleh orang tua, bukan yang dipelajari secara professional.

Berdasarkan bangunan struktur sosial, komunitas nelayan terdiri atas komunitas yang heterogen dan homogen. Masyarakat yang heterogen adalah mereka yang bermukim di desa-desa yang mudah dijangkau secara transportasi darat, sedangkan komunitas yang homogen terdapat di desa-desa nelayan terpencil biasanya menggunakan alat-alat tangkap ikan yang sederhana, sehingga produktivitas kecil. Sementara itu kesulitan transportasi angkutan hasil ke pasar juga akan menjadi penyebab rendahnya harga hasil laut di daerah mereka.

\subsection{Pengertian Aplikasi Mobile}

Menurut Buyens (2001) aplikasi mobile berasal dari kata Application dan mobile. Application yang artinya penerapan, lamaran, penggunaan. Secara istilah aplikasi adalah program siap pakai yang direka untuk melaksanakan suatu fungsi bagi pengguna atau aplikasi yang lain dan dapat digunakan oleh sasaran yang dituju sedangkan mobile dapat di artikan sebagai perpindahan dari suatu tempat ke tempat yang lain. Kata mobile mempunyai arti bergerak atau berpindah, sehingga aplikasi mobile menurut Purnama ( 2010) adalah sebutan untuk aplikasi yang berjalan di mobile device.Dengan menggunakan aplikasi mobile, dapat dengan mudah melakukan berbagaii macam aktifitas mulai dari hiburan, berjualan, belajar, mengerjakan pekerjaan kantor, browsing dan lain sebagainya.Pemanfaatan aplikasi mobile untuk hiburan paling banyak digemai oleh pengguna telepon seluler, karena dengan memanfaatkan adanya fitur game, music player, sampai video player membuat kita mejadi semakin mudah menikmati hiburan kapan saja dan dimanapun.Perangkat mobile memiliki banyak jenis dalam hal ukuran,desai layout, tetapi memreka memiliki kesamaan karakteristik yang sanagt berbeda dari dekstop system. Perangkat mobile memiliki memory yang kecil [4].

\subsection{Penelitian terdahulu}

Untuk visualisasi obyek keberhasilannya adalah $69 \%$. Untuk visualisasi jarak. Bisa terbaca dengan baik pada jarak objek lima mater kebawah dasar laut. Sistem Pengelolaan Kelautan Berupa Usv Semiautomatic Pendeteksi Minyak Dan Ikan menghasilkan bahwa sistem ini kecelakan laut yang mengakibatkan tumpahan minyak dalam jumlah yang besar dapat segera diatasi. Pembuatan kapal tanpa awak ini sebaiknya juga dilengkapi dengan sensor yang mampu mendeteksi kandungan zat kimia dalam suatu cairan, selain 
itu juga diperlukan sistem komunikasi yang lebih efektif pada kapal dan ground station. Penelitian tentang penggunaan aplikasi juga pernah dilakukan oleh Marliana (2012), yaitu dengan memanfaatkan aplikasi sebagai agenda untuk mengingkat kegiatan yang akan dilakukan [3].

\section{HASIL DAN PEMBAHASAN}

Adapun Penelitian ini berisi pengenalan fitur aplikasi mobile Zagiyan yaitu :

1. Fitur Beranda

Fitur Beranda berisi Fitur yang berisi Profil User dan kumpulan fitur Zagiyan. Adapun tampilannya sebagai berikut :

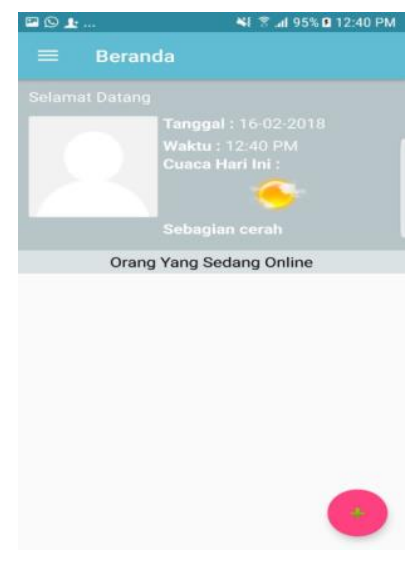

\section{Gambar 1. Fitur Beranda}

2. Fitur Harga Ikan

Fitur Harga Ikan berisi Fitur yang berisi kumpulan harga ikan yang berasal dari kementrian perikanan dan Kelautan Adapun tampilannya sebagai berikut :

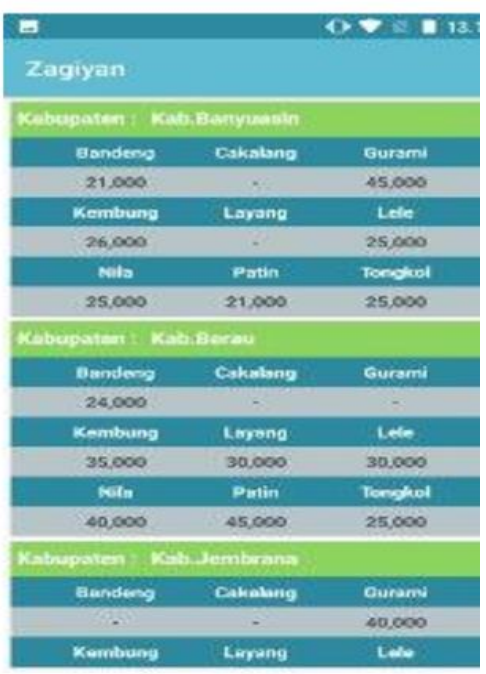

Gambar 2. Fitur Harga Ikan 


\section{Fitur Laporan Pendapatan}

Fitur Laporan Pendapatan berisi Fitur yang laporann pendapatan nelayan yang dapat dimodifikasi oleh nelayan secara individu sehingga dapat meminimalisir laporan pendapatan yang manual Adapun tampilannya sebagai berikut :

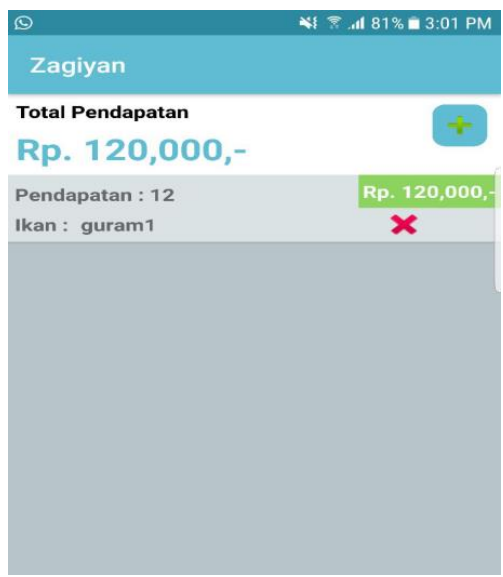

Gambar 3. Laporan Pendapatan

4. Fitur Info Cuaca

Fitur Info Cuaca berisi Laporan Cuaca yang dapat update secara real time setiapharinya. Adapun tampilannya sebagai berikut :

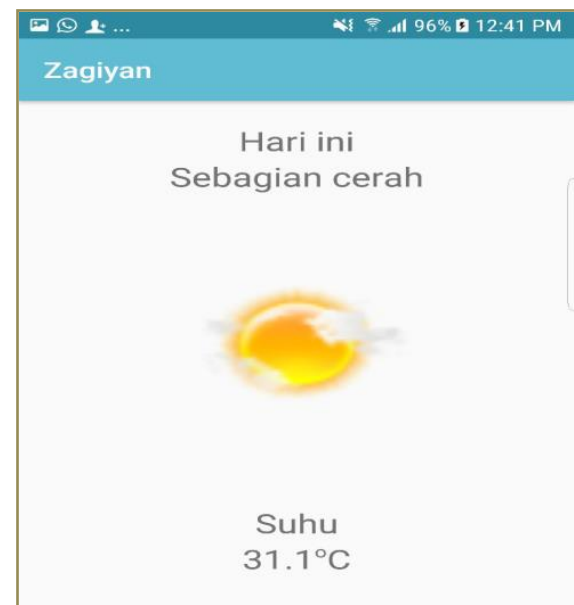

Gambar 4. Fitur Info Cuaca

5. Fitur Info Puskesmas

Fitur Info Puskesmas berisi data puskesmas yang terdapat di sekitar lokasi tempat tinggal nelayan . Adapun tampilannya sebagai berikut : 


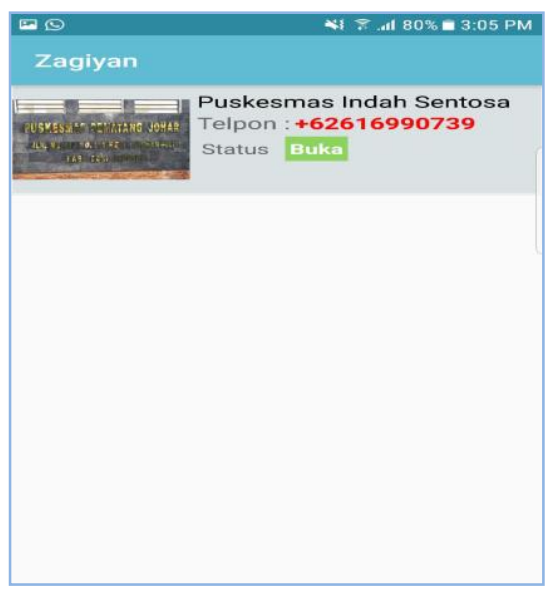

\section{Gambar 5 . Fitur Info Puskesmas}

6. Fitur Info Koperasi

Fitur Info Koperasi berisi data Koperasi yang terdapat di sekitar lokasi tempat tinggal nelayan. Adapun tampilannya sebagai berikut :

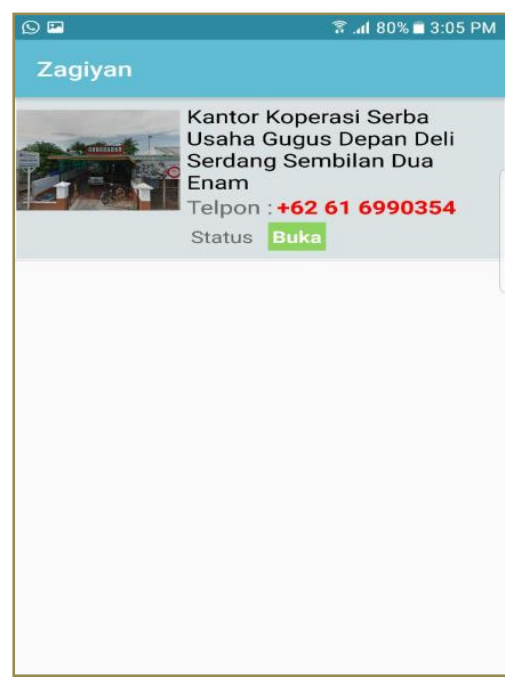

\section{Gambar 6 . Fitur Info Koperasi}

7. Fitur Info Perikanan dan Kelautan

Fitur Info Perikanan dan Kelautan berisi data Info Perikanan dan Kelautan yang berasal dari Kementrian Perikanan dan Kelautan Adapun tampilannya sebagai berikut : 


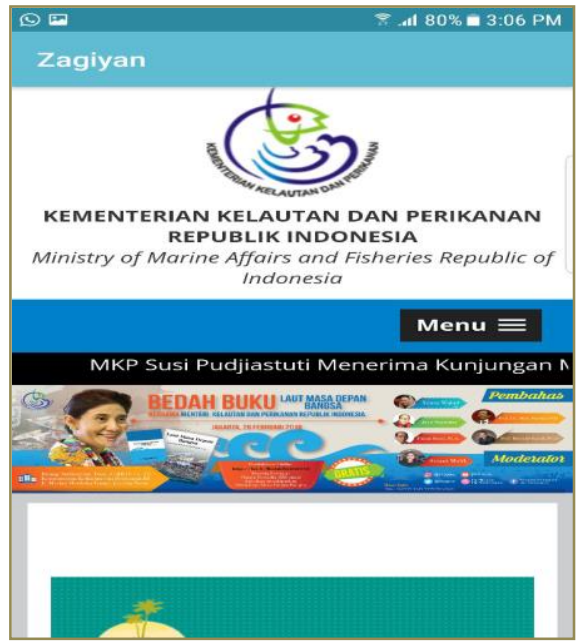

\section{Gambar 7 . Info Perikanan dan Kelautan}

8. Fitur Check In

Fitur Check In merupakan Fitur unggulan yang berfungsi untuk check keberadaan ikan oleh nelayan secara real time, sehingga nelayan dapat kembali lagi kapan pun Adapun tampilannya sebagai berikut :

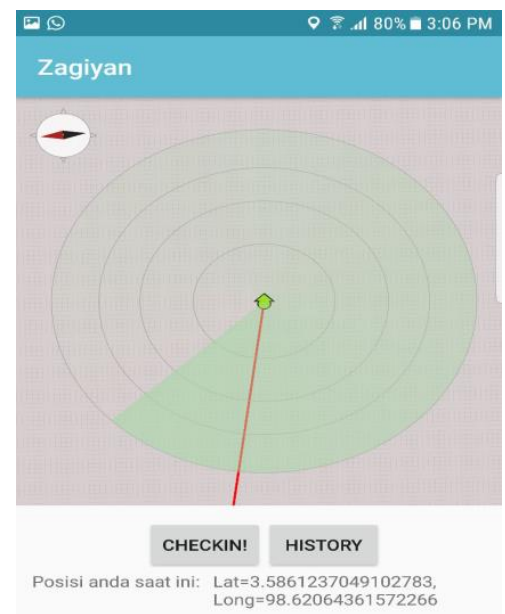

\section{Gambar 8 . Fitur Check In}

9. Fitur Panik

Fitur Panik adalah fitur yang digunakan oleh nelayan jika terjadi kecelakaan ataupun pembajakan ikan, dengan fitur ini nelayan dapat menghubungi polisi air dan keluarga terdekat hanya dengan menekan tombol panik Adapun tampilannya sebagai berikut : 


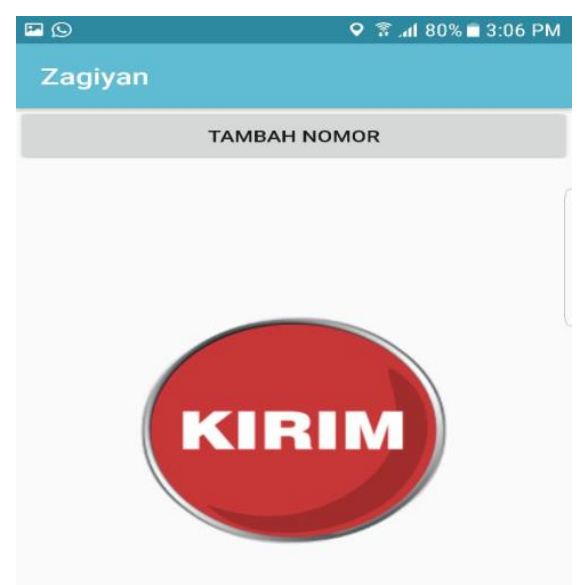

\section{Gambar 9 . Fitur Panik}

\section{Fitur Report}

Fitur Report adalah fitur yang digunakan oleh nelayan jika terjadi pembajakan ataupun pencurian ikan oleh nelayan asing . Report ini dapat langsung terkirim ke polisi air terdekat

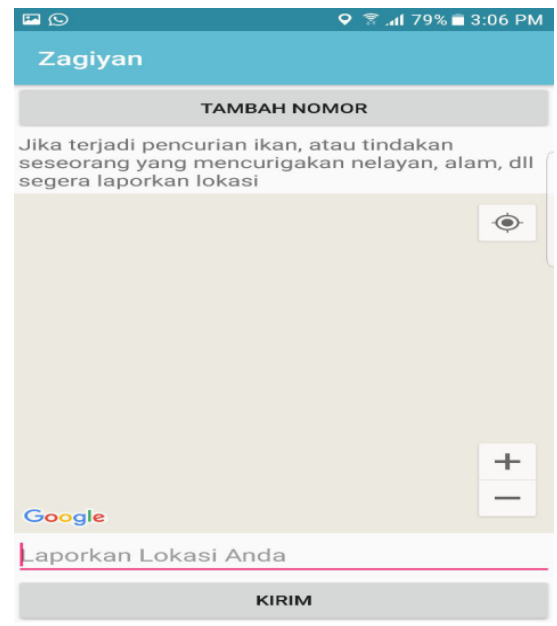

\section{Gambar 10 . Fitur Report}

11. Fitur E- P3K

Fitur E- P3K adalah fitur yang digunakan untuk mendapatkan pertolongan pertama jiak terjadi insiden seperti terkena racun ikan dan lain - lain. 


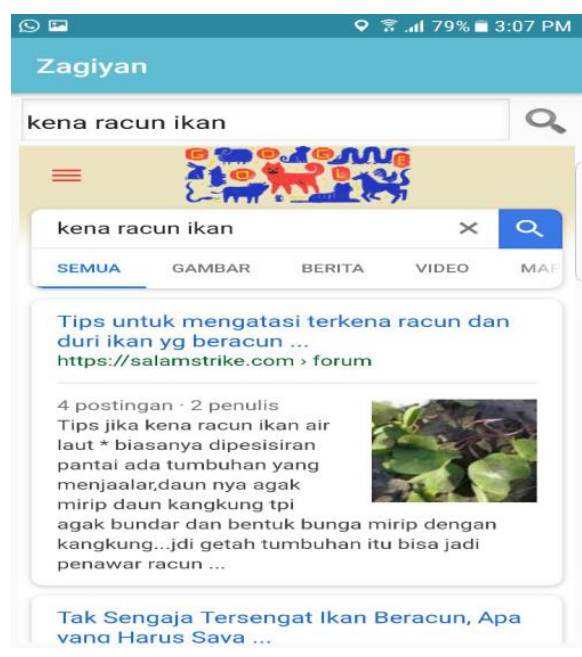

Gambar 11 . Fitur E- P3K

\section{KESIMPULAN DAN SARAN}

Adapun kesimpulan dari hasil penelitian ini adalah :

1. Aplikasi ini dapat mempermudah pekerjaan nelayan saat melaut karena sistem sudah terintegrasi.

2. Aplikasi ini dapat Meningkatkan produktivitas, Pelayanan kesehatan, dan Keselamatan Nelayan.

3. Aplikasi ini dapat mempermudah pekerjaan nelayan saat melaut karena sistem sudah terintegrasi

4. Aplikasi ini dapat Meningkatkan produktivitas, Pelayanan kesehatan, dan Keselamatan Nelayan.

5. Diharapkan kepada peneliti selanjutnya untuk dapat mengembangan sistem ini dengan tingkat keakuratan yang lebih tinggi atau $>95 \%$.

\section{DAFTAR PUSTAKA}

[1] Harahap S A. dan Yanuarsyah, 2012. Aplikasi Sistem Informasi Geografis Untuk Zonasi Jalur Penangkapan Ikan di Perairan Kalimantan Barat. Jurnal Aquatika. Vol III. No I Maret 2012. Hal: 40-48

[2] Hutahean Japerson, 2015. Konsep Sistem Informasi. Yogyakarta : Penerbit Deepublish.

[3] Marliana. 2012. Penerapan Agenda Pengingat Berbasis Aplikasi. Prosiding SnaPP 2014 Sains, Teknologi dan Kesehatan. Volume 3 Nomor 1, Tahun 2012.

[4] Purnama, Rangsang. 2010. Pemrograman J2ME Tingkat Dasar, PT. Gitamedia Publisher, Surabaya.

[5] Rahmawati ID, Saidi Ida A dan Sari DK. 2014. IbM Kelompok Petambak Tradisional Ikan Bandeng Dalam Bentuk Diversifikasi Produk Olahan Berkualitas Untuk Meningkatkan Pendapatan Petambak Pasca Terjadinya Lumpu Lapindo di Desa Banjarpanji Tanggulangin. Prosiding SnaPP 2014 Sosial, Ekonomi dan Humaniora Volume 4 Nomor 1, Tahun 2014. 
IT Journal Research and Development

Vol.2, No.2, Maret 2018

e-ISSN: 2528-4053

[6] Sastrawidjaya, 2002. Nelayan Nusantara. Pusat Riset Pengolahan Produk Sosial Ekonomi Kelautan dan Perikanan. Jakarta. 